DOI: https://doi.org/10.24127/ajpm.v10i1.3216

\title{
PENGEMBANGAN LEMBAR KEGIATAN SISWA BERBASIS CHALLENGE BASED LEARNING PADA MATERI PELUANG
}

\author{
Putri Cahyani Agustine', Fitri Apriani \\ ${ }^{1,2}$ Universitas Muhammadiyah Bangka Belitung, Kabupaten Bangka Tengah, Indonesia \\ ${ }^{*}$ Corresponding author. \\ E-mail: putri.cahyaniagustine@ stkipmbb.ac.id $^{1)}$

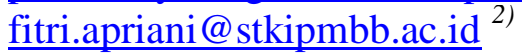

Received 06 November 2020; Received in revised form 06 March 2021; Accepted 06 April 2021

\begin{abstract}
Abstrak
Penelitian ini bertujuan untuk menghasilkan produk pengembangan dan mengetahui kelayakan Lembar Kegiatan Siswa (LKS) berbasis challenge based learning materi peluang di kelas 8 SMP Negeri 5 Pangkalpinang. Penelitian ini adalah penelitian pengembangan melalui dua tahap yaitu tahap preliminary yang meliputi persiapan dan desain dilanjutkan tahap formative evaluation yang meliputi self evaluation, expert reviews, one-to-one, small group, dan fieldtest. Penelitian ini menghaslkan LKS Berbasis Challenge Based Learning materi peluang dengan sampel 38 orang siswa. Teknik pengumpulan data dengan lembar observasi,angket, tes, dan dokumentasi. Data tersebut dianalisis agar instrumen yang dihasilkan valid dan praktis. Valid tergambarkan berdasarkan penilaian validator dari segi konten (isi), konstruk, dan bahasa. Kepraktisan tergambar dari hasil uji coba pada tahap small group. Dari hasil analisis data kelayakan isi 3,55 kategori sangat baik, kelayakan penyajian 3,65 kategori sangat baik, dan kelayakan bahasa 3,12 kategori baik. Dari hasil penelitian telah dihasilkan produk LKS berbasis challenge based learning pada materi peluang.
\end{abstract}

Kata kunci: Challenge based learning; peluang; pengembangan.

\begin{abstract}
This research aims to produce development products and determine the feasibility of student activity based on challenge based learning worksheet opportunities material in grade 8 at SMP Negeri 5 Pangkalpinang. This research is a development research through two stages, first the preliminary stage consist of preparation and design. The Second is formative evaluation stage consist of self-evaluation, expert reviews, one-to-one, small group, and field test. This research produce Challenge Based Learning worksheet in opportunities material and sample consist of 38 students. The technique of collecting data by observation sheets, questionnaires, tests, and documentation. The data is analyzed so that the resulting instrument is valid and practical. Valid is described based on the validator's assessment in terms of content, construct, and language. Practicality is illustrated by the trial results at the small group stage. From the results of data analysis, the feasibility of the contents of the 3.55 categories is very good, the feasibility of serving 3.65 categories is very good, and the language feasibility is 3.12 categories are good. From the research results have produced LKS based challenge based learning on opportunity material.
\end{abstract}

Keywords: Challenge based learning; development; opportunities.

This is an open access article under the Creative Commons Attribution 4.0 International License

\section{PENDAHULUAN}

Memasuki era revolusi industri
4.0 harus diimbangi dengan
pembaharuan pembelajaran yang ada di
kelas. Matematika memiliki peranan yang amat penting dalam kehidupan sehari-hari. Segala sesuatu tidak lepas dari matematika bahkan ilmu pengetahuan seperti fisika, kimia, biologi, komputer dan lain sebagainya 
juga tidak lepas dari peran matematika didalamnya (Apriani \& Agustine, 2019). Pembelajaran matematika Menurut (Tandaliling, 2011) mengatakan bahwa pembelajaran matematika di kelas harus direformasi sebagai upaya mengantisipasi perkembangan ilmu pengetahuan dan teknologi yang semakin maju. Hakikat belajar matematika menurut Hudoyo merupakan kegiatan mental yang tinggi dimana melibatkan ide-ide, strukturstruktur dan hubunganhubungan yang disusun secara hierarki dengan alasan yang logis (Hasratuddin, 2013). Oleh karena itu, pembelajaran seharusnya dapat mengembangkan kemampuan siswa untuk menyelesaikan suatu permasalahan.

Selama ini, hasil yang dinilai dalam pembelajaran matematika hanyalah aspek kognitif, tanpa melihat aspek afektif. Padahal asfek kognitif dan aspek afektif saling mempengaruhi satu sama lain. Menurut (Haqq, 2017) salah satu faktor terpenting dalam menentukan keberhasilan siswa dalam belajar matematika pada proses pembelajaran adalah Aspek Afektif. Sabandar mengatakan bahwa kemampuan kognitif tidak akan berkembang jika aspek afektif tidak disertakan dalam pembelajaran matematika (Prabowo, 2010) Dipertegas oleh (Ismayani, 2016)) yang mengatakan ternyata aspek kognitif yang diasosiasikan dengan kecerdasan bukan satu-satunya syarat mutlak untuk tumbuhnya kreativitas. Aspek afektif akan lebih mudah dipahami jika siswa diberikan kesempatan untuk mengembangkannya. Oleh karena itu, dalam pembelajaran matematika yang harus dikembangkan adalah aspek kognitif dan aspek afektifnya.

Upaya untuk mengembangkan kedua aspek tersebut tentunya diperlukan pembelajaran yang dapat merangsang minat belajar melalui learning by doing. Pembelajaran matematika melalui learning by doing ini, salah satunya dapat diterapkan melalui Challenge-based Learning (CBL) (Haqq, 2017) CBL adalah pendekatan pembelajaran yang memberikan pengalaman kepada siswa dalam bentuk pengetahuan dengan menggabungkan pembelajaran berbasis masalah, pembelajaran berbasis proyek dan pembelajaran kontekstual pada pemecahan masalah dunia nyata (Nufus, 2018) Sejalan dengan pendapat (Sodikin, 2014) model CBL dalam penelitian terdapat enam tahap yaitu: Big Idea, Essensial Question, The Challage, Guiding Question, Guiding Activity, dan Solusion. Diperjelas oleh Baloian mengatakan bahwa pembelajaran dengan pendekatan CBL dapat meningkatkan problem solving skill dan creativity (Junita, 2016) Sehingga CBL diharapkan bisa mengembangan pengetahuan dan meningkatkan kreatifitas siswa dalam pembelajaran matematika.

Namun, berdasarkan hasil pengamatan yang dilakukan di SMP Negeri 5 Pangkalpinang siswa tidak mengikuti pembelajaran dengan maksimal karena bahan ajar yang digunakan oleh guru kurang relevan dengan materi peluang. Hal ini diungkapkan oleh salah satu guru matematika kelas 8 SMP Negeri 5 Pangkalpinang mengatakan bahwa hasil ujian materi peluang siswa rendah. Padahal materi peluang penting sebagai langkah awal dalam mengambil sebuah keputusan. Peluang merupakan bagian dari matematika yang perlu dikuasai siswa sekolah menengah sebagai prasyarat materi statistik yang sangat banyak digunakan dalam merancang penelitian dan mengolah data hasil 
penelitian dari berbagai cabang ilmu (Azhar, 2011). Menurut (Yusuf, 2009) gambaran yang tampak dalam bidang pendidikan selama ini, pembelajaran menekankan lebih pada hafalan dan mencari satu jawaban yang benar untuk soal-soal yang diberikan, proses pemikiran tinggi termasuk berpikir kreatif jarang dilatihkan. Selain metode yang digunakan, keberhasilan dalam pembelajaran juga tergantung pada perangkat pembelajaran yang digunakan seperti bahan ajar yang dapat dijadikan sebagai alat bantu dalam pembelajaran yang disajikan menarik dan sistematis.

Salah satu cara mengatasi permasalahan di atas dengan mengembangkan bahan ajar yang dapat diaplikasi dalam pembelajaran matematika seperti LKS berbasis challenge based learning. LKS merupakan stimulus atau bimbingan guru dalam pembelajaran yang akan disajikan secara tertulis sehingga dalam penulisannya perlu memperhatikan kriteria media grafis sebagai media visual untuk menarik perhatian peserta didik (Fannie, 2014) serta membuat prestasi belajar siswa meningkat (Toman, 2013). Ditambahkan pula sebelum merancang LKS peneliti sebaiknya melakukan analisis siswa untuk mengetahui kemampuan (tinggi, sedang, rendah), analisis kurikulum untuk mengetahui batasan materi yang telah dipelajari, dan analisis LKS untuk memastikan kesesuaian LKS dengan karakteristik siswa (Agustine, 2019).

Adapun keunggulan dari CBL menurut (Nawawi, 2016) keunggulan integrasi model pembelajaran CBL antara lain siswa aktif dalam pembelajaran, bab siswa berpikir bagaimana memecahkan masalah yang dihadapi, masalah muncul dari kehidupan sehari-hari maupun berakar dari permasalahan atau isu-isu global, dan dilakukan sebuah perencanaan untuk (Haqq, 2017) (Fannie, 2014) penyelesaiannnya. Siswa ditantang untuk menyelesaikan permasalahan yang dihadirkan atau proyek yang harus diselesaikan. Tindakan nyata dan solusi yang berasal dari hal-hal yang sederhana bisa ditemukan dalam kehidupan sehari-hari.

Menurut (Nichols, 2016) Keberhasilan pembelajaran dengan pembelajaran challenge based learning dipengaruhi oleh beberapa tahapan diantaranya 1) Engage, yang diawali dengan menghadirkan gagasan utama (big idea). Dilanjutkan dengan siswa membangun pertanyaan penting (esensial questions) terkait gagasan utama dan tantangan diberikan agar siswa dapat mengembangkan masalah sampai memperoleh jawaban (challenge). 2) Investage. Dilanjutkan dengan guru memberikan pertnyaan pemandu (guiding questions) dan kegiatan pemandu (guiding resources). Melalui kegiatan tersebut, siswa berkolaborasi dengan guru untuk menganalisis jawaban (analysis). 3) Act. Siswa melaksanakan strategi yang telah ditetapkan dan menentukan solusi akhir dari tantangan.

Beberapa penelitian terkait challange based learning yaitu penelitian berjudul pengaruh model challenge based learning terhadap hasil belajar matematika pada materi persegi dan persegi panjangbagi siswa kelas VII SMP Negeri 2 Tuntang (Astuti S. D., 2016) dan penelitian berjudul Implementasi Challenge Based Learning dalam Upaya Meningkatkan Kemampuan Penalaran Matematis Siswa SMA (Haqq, 2017). Dipertegas oleh menyebutkan bahwa Challenge Based Learning mempunyai kelebihan dapat meningkatkan keterlibatan siswa dalam pembelajaran. Dari penelitian 
dan pendapat yang telah dikemukakan, belum ada penelitian yang mengembangkan LKS berbasis challenge based learning pada materi peluang di kelas 8 SMP. Oleh karena itu penelitian ini mengembangkan produk bahan ajar berbentuk LKS berbasis challenge based learning yang diimplementasikan pada materi peluang. Hasil yang diharapkan pada penelitian ini menghasilkan LKS berbasis challenge based learning yang valid dan praktis.

\section{METODE PENELITIAN}

Metode penelitian pengembangan atau development research adalah tahap preliminary dan tahap formatif evaluation. Tahap preliminary dan tahap formative evaluation yang meliputi self evaluation, prototyping (expert review, one to one, dan small group). Penelitian ini dilaksanakan untuk mengembangkan dan menghasilkan sebuah produk sebagai solusi dari masalah dalam pembelajaran matematika. Produk yang dihasilkan adalah LKS berbasis challenge based learning materi peluang kelas 8 SMP. Subjek penelitian adalah siswa kelas 8 SMP Negeri 15 Pangkalpinang sebanyak 38 orang siswa. Teknik pengumpulan data meliputi target, metode, instrumen, dan subjek disajikan pada Tabel 1. Analisis data komentar dari siswa dan guru serta analisis data hasil belajar siswa dalam pembelajaran dianalisis berdasarkan kategori nilai pada Tabel 2.

Tabel 1. Teknik pengumpulan data.

\begin{tabular}{lllll}
\hline No & Target & Metode & Instrumen & Subjek \\
\hline 1 & Komentar Siswa & wawancara & Lembar observasi & Siswa \\
2 & Komentar Validator & $\begin{array}{l}\text { Angket dan } \\
\text { wawancara }\end{array}$ & $\begin{array}{l}\text { Lembar observasi } \\
\text { dan angket }\end{array}$ & Validator \\
3 & Hasil Belajar Siswa & Tes & Soal tes & Siswa \\
\hline
\end{tabular}

Tabel 2. Kategori nilai.

\begin{tabular}{ccl}
\multicolumn{2}{c}{ Skor $\quad$ Konversi } & \multicolumn{1}{c}{ Kriteria } \\
\hline $85-100$ & $3,4-4$ & Sangat Tinggi/sangat valid \\
$70-84$ & $2,8-3,3$ & Tinggi/ valid \\
$60-69$ & $2,4-2,76$ & Cukup/cukup valid \\
$51-59$ & $2,04-2,3$ & Rendah/kurang valid \\
$0-50$ & $0-2$ & Sangat Rendah/tidak valid \\
\hline
\end{tabular}

(Ratnawulan, 2014)

\section{HASIL DAN PEMBAHASAN}

Proses pengembangan bahan ajar melalui dua tahap yaitu tahap preliminary yang meliputi persiapan dan desain kemudian formative evaluation yang meliputi self evaluation, expert reviews, one-to-one, small group, dan field test.

A. Preliminary, terbagi menjadi 2 tahap yaitu a. Persiapan b. Desain. Pada tahap ini kegiatan yang telah dilaksanakan meliputi melakukan analisis siswa, analisis kurikulum, analisis LKS dan desain LKS.

B. Formative Study terbagi 1. Self Evaluation, dalam self evaluation, perangkat pembelajaran yang telah dibuat dievaluasi oleh peneliti sendiri kemudian dinamakan prototype pertama. 2. Expert reviews, pada tahap 
DOI: $\underline{\text { https://doi.org/10.24127/ajpm.v10i1.3216 }}$

ini, prototype pertama divalidasi oleh empat orang pakar yang bertujuan untuk memperoleh bahan ajar yang valid. Prototype pertama divalidasi dari segi konten, konstruk dan bahasa. Empat orang pakar tersebut yakni:

a. Indah Riezky Pratiwi, M.Pd., dosen Politeknik Manufaktur Negeri Bangka Belitung,

b. Nurjanah, M.Pd., dosen Bahasa Indonesia Universitas Muhammadiyah Bangka Belitung,

c. Indah Widyaningrum, M.Pd., dosen Pendidikan Matematika STKIP Muhammadiyah Pagaralam,

d. Dewi Mulyati, S. Pd., Guru Matematika SMP Negeri 5 Pangkalpinang, yang mengajar pada kelas yang dilaksanakan penelitian.

Dari validasi berikan beberapa kritik dan saran yang menjadi bahan evaluasi untuk LKS prototipe 2.

C. One-to-one, seiring dilaksanakannya tahap expert reviews, dilakukan pula tahap one-to-one. Dalam proses ini ketua peneliti. Tahap one-to-one dilakukan terhadap tiga orang siswa kelas 8 SMP bernama MFT, AF dan AA. Ketiga siswa diminta untuk mengerjakan bahan ajar dan peneliti berinteraksi dengan siswa untuk melihat kesulitan-kesulitan yang mungkin terjadi dalam penggunaan bahan ajar sehingga dapat memberikan masukan atau koreksi apabila ada yang perlu diperbaiki.

Setelah di uji coba, siswa diminta untuk berkomentar secara bebas mengenai ketertarikan, kesulitan, komentar ataupun saran terhadap bahan ajar pada lembar observasi. Kemudian hasil uji coba dan komentar dari one-toone dan expert reviews dianalisis, direvisi kemudian disebut prototype kedua. Berikut pada Gambar 1 dan Gambar 2 diperlihatkan beberepa perubahan LKS prototype pertama dan prototype 2 dari LKS 1.

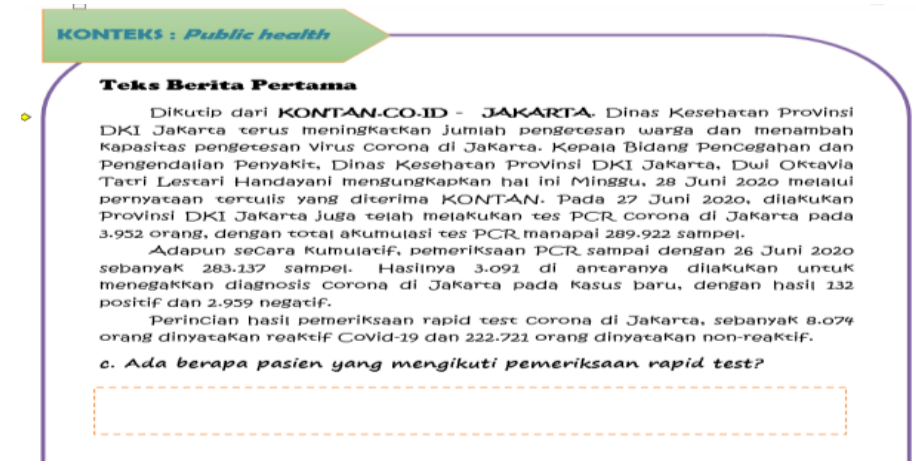

Gambar 1. Prototype pertama LKS 1

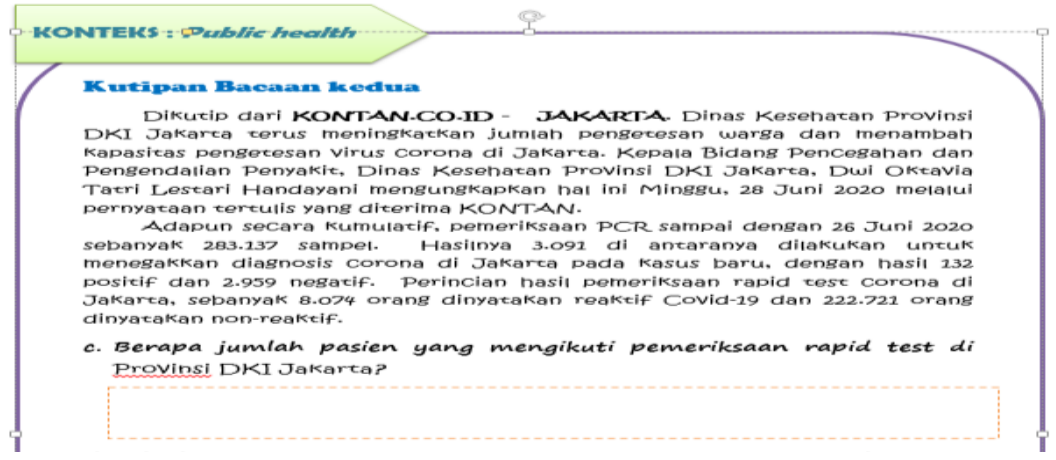

Gambar 2. Prototype kedua LKS 1 
DOI: $\underline{\text { https://doi.org/10.24127/ajpm.v10i1.3216 }}$

Berdasarkan Gambar 1 dan Gambar 2 dapat dilihat ada beberapa revisi terkait bahasa pada gambar 1 Kata "Teks Berita" direvisi menjadi "kutipan bacaan", sebagian kalimat "Pada 27 Juni 2020, dilakukan Provinsi DKI Jakarta juga telah melakukan tes PCR corona di Jakarta pada 3.952 orang, dengan total akumulasi tes PCR mancapai 289.922 sampel” menimbulkan kesalapahaman pada siswa sehingg dihilangkan, dan pada poin c kata "ada berapa" direvisi menjadi "berapa jumlah" atas saran ahli bahasa.

Gambar 3 dan Gambar 4 menunjukkan LKS prototype pertama dan prototype 2 , serta menampilkan perubahan dari prototype 1 dan 2 .

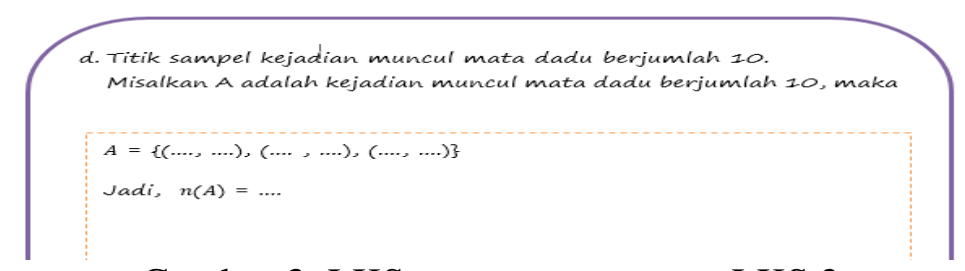

Gambar 3. LKS prototype pertama LKS 2

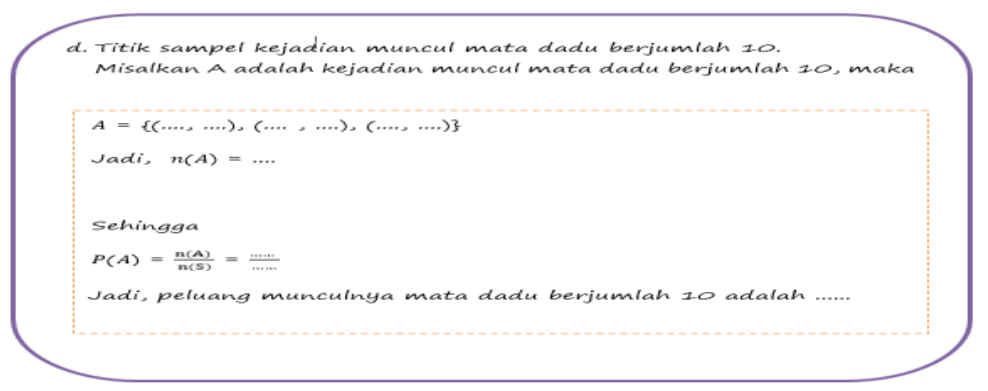

Gambar 4. LKS prototype kedua

Berdasarkan Gambar 3 dan Gambar 4 dapat dilihat ada beberapa revisi terkait penulisan tanda kurung pada kolom jawaban semula $A=$ $\{(4, \ldots),.(5, \ldots .),.(6, \ldots .)$.$\} menjadi A=$ $\{(\ldots \ldots, \ldots),.(\ldots ., \ldots),.(\ldots ., \ldots .)$.$\} agar siswa$ lebih mandiri dalam penyelesaian jawaban. Berikut pada gambar 5 dan gambar 6 diperlihatkan beberepa perubahan LKS prototype pertama dan prototype 2 dari LKS 3

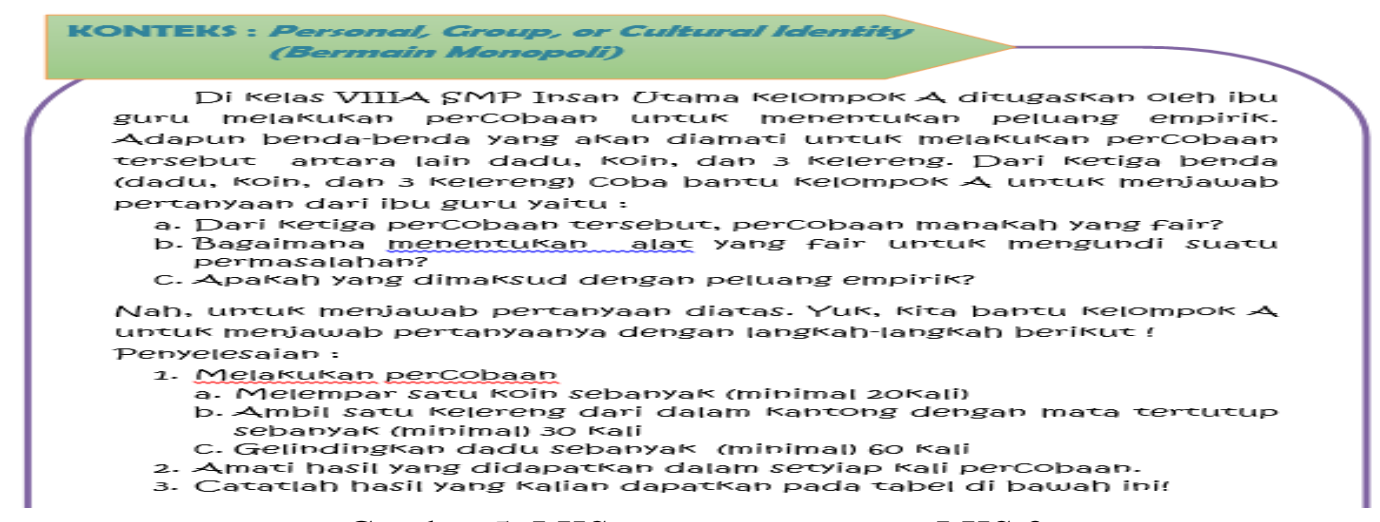

Gambar 5. LKS prototype pertama LKS 3 
DOI: https://doi.org/10.24127/ajpm.v10i1.3216

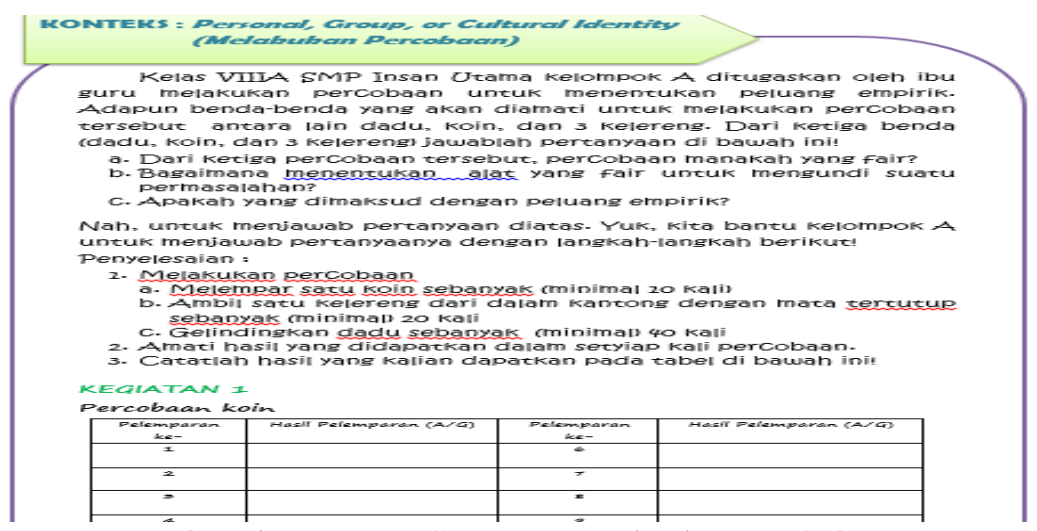

Gambar 6. LKS prototype kedua LKS 3

Dari Gambar 5 dan Gambar 6 dapat dilihat ada beberapa revisi terkait bahasa seperti kata "Di kelas VIIIA" pada kalimat pertama direvisi menjadi "Kelas VIIIA", dan kalimat " Dari ketiga benda (dadu, koin, dan 3 kelereng) coba bantu kelompok A untuk menjawab pertanyaan dari ibu guru yaitu" direvisi menjadi "Dari ketiga benda (dadu, koin, dan 3 kelereng) jawablah pertanyaan di bawah ini!" karena kurang efektif.

Berdasarkan uji validitas oleh ahli dan komentar siswa, dapat disimpulkan bahwa desain produk LKS prototype pertama yang dikembangkan dinyatakan valid dan telah direvisi menjadi prototype kedua berdasarkan saransaran yang diberikan.
C. Small Group, LKS yang telah direvisi berdasarkan expert review dan one-to-one dinamakan prototype 2 . LKS yang telah direvisi tersebut diujicobakan pada small group yang terdiri dari 3 orang siswa kemudian dianalisis mengahsilkan prototype 3.

D. Fieldtest, dilaksanakan sebanyak 3 kali pertemuan dimana 1 kali pertemuan berlangsung selama 2x40 menit kepada siswa-siswi SMP Negeri 5 Pangkalpinang dengan jumlah peserta didik 38 orang yang terdiri dari 21 orang peserta didik laki-laki dan 17orang peserta didik perempuan. Setelah dilakukan pengujian, diperoleh hasil akhir seperti yang disajikan pada Tabel 3.

Tabel 3. Kategori nilai akhir

\begin{tabular}{lll}
\hline Tahap CBL & Skor & Kriteria \\
\hline Big Idea & 3,33 & Tinggi \\
\hline Esensial Question & 3,33 & Tinggi \\
\hline The Challenge & 3 & Tinggi \\
\hline Solution & 2,67 & Cukup \\
\hline Evaluation/Assesment & 3 & Tinggi \\
\hline
\end{tabular}

Dari Tabel 3, skor tertinggi pada tahap big idea pada soal 1a dan $1 \mathrm{~b}$ dan esensial question pada soal 1c dengan skor 3,33 kategori baik dan skor terendah pada tahap solution soal $2 \mathrm{~d}$ dengan skor 2,67 kategori cukup. Hal ini membuktikan bahwa LKS sudah berbasis challenge based learning sudah baik. Disamping itu, diperoleh juga hasil dari kelayakan produk seperti yang disajikan pada Tabel 4. 
DOI: https://doi.org/10.24127/ajpm.v10i1.3216

Tabel 4. Aspek kelayakan.

\begin{tabular}{ccc}
\hline Aspek Kelayakan & Skor rata-rata & Kategori \\
\hline Isi & 3,55 & Sangat Valid \\
\hline Penyajian & 3,65 & Sangat Valid \\
\hline Bahasa & 3,12 & Valid \\
\hline
\end{tabular}

Dari Tabel 4 dapat dilihat bahwa aspek kelayakan yang paling tinggi adalah kelayakan penyajian dengan skor rata-rata 3,65 dan aspek kelayakan isi dengan skor 3,55 kategori sangat valid. Sedangkan aspek kelayakan bahasa skor rata-rata 3,12 dengan kategori valid.

LKS merupakan lembaranlembaran berisi tugas yang hasrus dikerjakan oleh siswa (Haryonik, 2018). Ditambahkan pula menurut (Astuti \& Sari, 2017) Penilaian lembar kerja siswa yang sudah dikembangkan dinilai oleh pakar pendidikan matematika berdasarkan pemikiran rasional belum berdasarkan fakta dilapangan. Jika terjadi ketidaksesuaian maka akan dilakukan perbaikan dengan meninjau kembali bahan ajar. Penilaian pakar sangat layak sebagai bahan ajar untuk materi peluang. Setiap langkah pada challenge based learning dilaksanakan dan kemudian direvisi sesuai dengan kritik dan saran yang didapatkan sehingga memenuhi kriteria layak sebagai bahan ajar untuk siswa kelas 8 SMP pada materi peluang. Menurut Swiden (2013) Pembelajaran dengan challenge based learning membuat siswa mampu bekerja bersama siswa lain dan guru-guru mereka. Dalam pelaksanaan LKS challenge based learning beberapa kelemahan yang ditemukan saat menerapkan LKS membutuhkan waktu yang relatif lama sehingga guru harus menggunakan waktu seefisien mungkin dalam menerapkan pembealajaran ini. Hal ini sejalan dengan pendapat (Astuti, 2016) mengatakan hal yang sama dalam penerapan challenge based learning membutuhkan waktu yang relatif lama. Oleh karena itu, diharapkan ketika menggunakan challenge based learning siswa diberikan petunjuk pelaksanaan pengerjaan LKS agar waktu efektif dan efisien.

Dampak dari penelitian dan pengembangan lembar kegiatan siswa berbasis challenge based learning pada materi peluang ini dapat memunculkan tahap big idea siswa dengan kriteria tinggi, tahap essensial question siswa dengan kriteria tinggi, tahap the challange siswa dengan kriteria tinggi, solution siswa dengan kriteria cukup, dan tahap evaluation/assesment siswa dengan kriteria tinggi.

\section{KESIMPULAN DAN SARAN}

Berdasarkan hasil penelitian yang telah dilakukan, maka dapat disimpulkan sebagai berikut: 1) telah dihasilkan LKS berbasis challenge based learning pada materi peluang yang valid dan praktis. 2) Dari hasil analisis small group pada big idea skor 3,33, Esenssial question skor 3,0, challenge skor3,0, dan evaluation skor 3 dengan kategori terendah tahap solution skor 2,67 dengan kategori cukup. 3) LKS yang dikembangkan dengan materi peluang dikembangkan sesuai dengan standar kompetensi dan kompetensi dasar, sangat menuntun siswa untuk melakukan kegiatan, layak sebagai media pembelajaran, dan efektif terhadap aktivitas dan hasil belajar siswa. 


\section{DAFTAR PUSTAKA}

Agustine, P. A. (2019). Perancangan Prototype LKS Materi Operasi Hitung Bilangan Bulat Untuk Peserta Dididk Sekolah Dasar. Jurnal Inomatika Inovasi Matematika 1(2), 132-143. https://doi.org/10.35438/inomati ka.v1i2.150.

Apriani, F., \& Agustine, P. C. (2019). Museum Timah Indonesia Pangkalpinang sebagai Alternatif Pembelajaran Materi Sudut. AKSIOMA: Jurnal Program Studi Pendidikan Matematika, 8(3), 395-407. http://dx.doi.org/10.24127/ajpm. v8i3.2276.

Apriani, F. (2015). Pendekatan Problem Based Learning (PBL) Pokok Bahasan Deret Aritmatika. Jurnal Dosen Universitas PGRI Palembang.

Astuti \& Sari, N. (2017). Pengembangan Lembar Kerja Siswa (LKS) Pada Mata Pelajaran Matematika Siswa Kelas X Sma. Jurnal Cendikia : Jurnal Pendidikan Matematika, 1(2), 13-24. https://doi.org/10.31004/cendeki a.v1i2.16.

Astuti, S. D. (2016). Pengaruh pengaruh model challenge based learning terhadap hasil belajar matematika pada materi persegi dan persegi panjangbagi siswa kelas VII SMP Negeri 2 Tuntang. Salatiga: FKIP Universitas Kristen Satya Wacana.

Azhar, E. D. (2011). Pengembangan Perangkat Pembelajaran Teori Peluang Berbasis RME Untuk Meningkatkan Pemahaman, Penalaran, dan Komunikasi Matematika Siswa SLTA.
Prosiding Seminar Nasional Matematika dan Pendidikan Matematika 2011 (pp. 213-222). Yogyakarta: Pendidikan Matematika FMIPA UNY.

Fannie, R. D. (2014). Pengembangan lembar kerja siswa (LKS) berbasis POE (predict, observe, explain) pada materi program linear kelas XII SMA. SAINMATIKA Jurnal Sains dan Matematika, 8(1), 96-109.

Haqq, A. (2017). Analsis Afektif Siswa Pada Pembelajaran Matematika dengan Menggunakan Model Challenge Based Learning. . Procediamath, 1(1), 82-94.

Haryonik, Y. (2018). Pengembangan bahan ajar lembar kerja siswa dengan pendekatan matematika realistik. Mapan Jurnal Matematika dan Pembelajaran, 6(1), 40-45. https://doi.org/10.24252/mapan. $2018 v 6$ n1a5.

Hasratuddin. (2013). Membangun Karakter Melalui Pembelajaran Matematika. Jurnal Paradikma, $130-141$.

Ismayani, A. (2016). Pengaruh penerapan STEM project-based learning terhadap kreativitas matematis siswa SMK. Indonesian Digital Journal of Mathematics and Education, 3(4), 264-272.

Junita, S. (2016). Peningkatan Kemampuan Creative Problem Solving Matematis Siswa SMP dengan Pendekatan Challenge Based Learning. Jurnal Pengajaran MIPA, 21(1), 19-23.

Kemendikbud. (2013). Kerangka Dasar dan Struktur Kurikulum 2013. Jakarta: Kemendikbud.

Nawawi, S. (2016). Potensi Model Pembelajaran Challenge Based 
DOI: https://doi.org/10.24127/ajpm.v10i1.3216

Learning

Dalam

Memberdayakan Kemampuan

Berpikir Kritis. Prosiding

Seminar Nasional Pendidikan,

1(1). Palembang: $\quad$ FKIP

Universitas Muhammadiyah

Palembang.

Nichols, M. C. (2016). Challenge Based

Leasrning. Redwood City.

CA:Digital Promise,

http://cbl.digitalpromise.org/wp-

content/uploads/sites/016/10/CB

L_Guide2016.pdf. Redwood:

CA : Digital.

Nufus, H. D. (2018). Mathematical

Creative Thinking and Student

Self-Confidence in the

Challenge-Based Learning

Approach. Journal of Research and Advances in Mathematics Education, 3(2), 57-68. 10.23917/jramathedu.v3i2.6367.

Prabowo, A. \&. (2010). Memahat Karakter Melalui Pembelajaran Matematika. In Proceeding of The 4th International Conference on Teacher Education (pp. pp. 165-177). Bandung: ProUPI \& UPSI Bandung.

Ratnawulan, E. D. (2014). Evaluasi Pembelajaran. Bandung: Pustaka Setia Bandung.

Sodikin, S. \&. (2014). Penerapan Model Challenge Based Learning dengan Metode Eksperimen Dan Proyek Ditinjau Dari Keingintahuan Dan Sikap Ilmiah Terhadap Prestasi Belajar Siswa. Jurnal Inkuir, 3, 129-139. https://doi.org/10.20961/inkuiri. v3i3.9722.
Swiden, C. L. (2013). Effect Of Challenge Based Learning On Student Motivation And Achievement. Montana: Montana State University .

Tandaliling. (2011). Peningkatan Pemahaman dan Komunikasi Matematis serta Kemandirian Belajar Siswa SMA Melalui Strategi PQ4R dan Bacaan Refutation Text. Bandung: SPs.UPI.

Toman. (2013). Extended Worksheet Developed According to $5 \mathrm{E}$ Model Based on Constructivist Learning Approach. International Journal on New Trends in Education and Their Implications, . International Journal on New Trends in Education and Their Implications., 4(4): 173-1

Yusuf, M. Z. (2009). Pengembangan Soal-soal Open-Ended pada pokok bahasan Segitiga dan Segiempat di SMP. Jurnal Pendidikan Matematika, 3(2), 48-56. 